\title{
Surgical Management of a Firearm Injury in the Infraorbital Area
}

\section{Manejo quirúrgico de una herida por arma de fuego en el área infraorbitaria}

\author{
Medina A. Heriberto DDS, OMFS1; Sansores E. Daniel DDS2; \\ González K. Debora DDS, M.P.D.1; Arriola P. Fabio DDS²
}

1. Department of Dentistry and Oral Maxillofacial Surgery of the Agustin O'Horan regional hospital in Merida, Mexico.

2. Private Practice in Merida, Mexico.

Correspondence to: Dr. Fabio Gregorio Arriola Pacheco - f-arriola@hotmail.com

Received: 3-VI-2017

Accepted: 26-VI-2017

Published Online First: 29-VI-2017

DOI: http://dx.doi.org/10.15517/ijds.v0i0.29643

\section{ABSTRACT}

The surgical management of firearm injuries to the zygomaticomaxillary complex is a topic that needs to be addressed with much care. The complications that can arise during treatment, as well as the potential residual problems that can appear, lead to the need of recognizing these injuries as a maxillofacial treatment challenge. The infraorbital zone is the second most common area of injury in the face, accounting for up to $45 \%$ of midfacial fractures. The case presented is of a 54 year old man affected by the backward firing of a gun rifle that caused an oblique impaction towards the posterior lateral inferior side of the infraorbital complex. He was rapidly stabilized with an antibiotic and analgesic scheme, yet presented the following: a comminute fracture of the orbit floor with consequent communication towards the maxillary sinus, a non-displacing fracture of the frontomalar suture, a non-displacing fracture of the zygomatic arch and a lesion with loss of osseous tissue in the petrous region of the temporal bone. Rigid fixation followed stabilization, and the area was covered with a titanium mesh. Occasional tinnitus and photopsia were reported by the patient upon return, yet all other evaluated factors were in order. There have been different forms of management described in the literature, and it is recognized that each patient has different needs, therefore each case must be closely evaluated, so it is approached in the most appropriate manner.

\section{KEYWORDS}

Firearm; Injury. 


\section{RESUMEN}

El manejo quirúrgico de las lesiones por armas de fuego al complejo cigomaticomaxilar representa una situación compleja en la práctica maxilofacial que debe ser abordada con extrema cautela, debido a las complicaciones que pueden surgir durante el tratamiento y los potenciales problemas residuales. La zona infraorbitaria es la segunda área más común de lesiones en la cara, representando hasta $45 \%$ de las fracturas mediocraneales. El presente caso es de un masculino de 54 años de edad, que sufrió trauma ocasionado por la parte trasera de un rifle de caza que causó un impacto en sentido oblicuo hacia el lado lateral inferior del complejo infraorbitario. El paciente fue estabilizado con esquema antibiótico y analgésico, el diagnóstico fue: fractura cominuta del piso de la órbita, con consecuente comunicación al seno maxilar, fractura no desplazada de la sutura frontomalar, fractura no desplazada del arco cigomático, y lesión con pérdida de tejido óseo en la región petrosa del hueso temporal. El tratamiento quirúrgico consistió en reducción de las fracturas y fijación rígida de las estructuras. Al control post operatorio el paciente refirió acufenos y fotopsia ocasional, no presentando otras alteraciones. Se ha descrito en la literatura diferentes abordajes para el manejo de estos traumatismos, sin embargo cada caso debe ser individualizado y evaluado de forma minuciosa para que éste, sea el adecuado.

PALABRAS CLAVE

Infraorbital; Arma de fuego.

\section{INTRODUCTION}

Firearm injuries represent some of the most complex and difficult challenges in maxillofacial surgery $(1,2)$. The fact that these encompass trauma to soft and neurological tissue, the bone and sense organs, lead to create a situation where much is compromised, not only for the practitioner, but also for the patient's quality of life (3). In the U.S., it has been reported that firearm injuries to facial and intracranial structures represent 15\% of all hospitalizations due these type of impacts (4). In a local, Mexican context, studies have reported that firearm injuries represent up to $20 \%$ of all impacts in hospitalized settings $(5,6)$. The infraorbital zone (the facial region below the orbit and lateral to the nose on each side) is the second most common area of injury in the face, only preceded by the nasal bone $(7,8)$. Trauma in this area accounts for $45 \%$ of midfacial injuries and $25 \%$ of all the fractures of the facial area (8). The reasons behind these injuries are multiple and include: violent assault, unintentional injuries (falls, transportation-related injuries, accidental injuries, such as in hunting), intentional injuries, forces of nature, war, and legal intervention $(9,10)$.

The typical management of these injuries requires primary focus on clearing and controlling the airway (patency), normally with a tracheostomy, followed by hemorrhage control $(2,3,11,12)$. Most of these procedures are then followed by hemodynamic resuscitation, evaluation of other affected areas and reconstructive surgery if needed $(11,12)$. Residual problems can appear in an individual manner, or mixed depending on the area and magnitude of the impact, and can include: nerve palsy, blindness, hemiparesis, mental/ psychiatric disorders, and epiphora $(11,12)$. As it can be noted, the complexity of management of these injuries, as well as the concomitant results and residual effects require a careful study of the case, as well as an understanding of what procedures are appropriate for each case. 


\section{CASE REPORT}

A 54 year old male patient was admitted to the emergency department of the Agustin $0^{\prime}$ Horan regional hospital with a metallic object impacted in the infraorbital region. He reported the accident to have happened whilst he was out hunting; in the moment when he activated his rifle's trigger, the posterior part of this projected outwards, provoking a penetrating wound in the infraorbital area. At arrival, the patient was in a conscious state, hemodynamically stable, with a non-compromised airway, but with edema in the affected zone and reporting general pain in the area. He referred loss of sensitivity of the tissues surrounding the nose, upper left lip, and lower left eyelid, leading to suspect of a direct lesion to the infraorbital nerve. He also referred tinnitus in the left ear, impossibility to open the left eye, and photopsia when he attempted to forcefully open the afore mentioned (Figure 1).

The patient was initially stabilized and managed IV with a double antibiotic scheme using: $1 \mathrm{~g}$. of ceftriaxone every 12 hours and $600 \mathrm{mg}$. of clindamycin every 12 hours ; $10 \mathrm{mg}$. of ketorolac and $25 \mathrm{mg}$. of tramadol every 8 hours where used for analgesic purposes. The integral evaluation of the wounds was carried out, by first cleaning the lesions with saline solution and then evaluating the tissue and structure loss. A teleradiography and CT scan revealed that the object had an oblique impaction direction towards the posterior lateral inferior side, therefore provoking the following: a comminute fracture of the orbit floor with the consequent communication towards the maxillary sinus, a non-displacing fracture of the frontomalar suture, a non-displacing fracture of the zygomatic arch and a lesion with loss of osseous tissue in the petrous region of the temporal bone (Figure 2 and 3 ).
Once the extension of the wound was determined, the surgical act followed. The first step consisted in removing, through traction, the impacted metallic object. In the part that was underlying inside the tissues, there was a metallic nut, which was part of the gun; with this finding it was necessary to assure it through clockwise rotatory movements, before actually performing the traction (Figure 4, 5, 6).

After clearing the object from the area, it was flushed with saline solution, with the debridement of the non-salvageable tissue followed by the reduction of the orbit floor fracture. Rigid fixation was then performed, previously having taken the appropriate measurements to design and place a titanium mesh that was fixed with titanium screws (Figure 7, 8, 9).

Primary closure of the wound followed, first suturing the muscular plane utilizing absorbable 3-0 polyglycolide acid suture and posteriorly closing the cutaneous plane with 4-0 nylon suture (Figure 10).

Pharmacologically, the patient was controlled with $1 \mathrm{~g}$. of cefiaxtrone every 12 hours, $600 \mathrm{mg}$. of clindamycin every 8 hours I.V., ophthalmologic Chloramphenicol eyedrops, $100 \mathrm{mg}$ of lysine clonixinate every 8 hours I.V., $30 \mathrm{mg}$. of ketorolac every 8 hours I.V., 2 drops of Softram eyedrops in the compromised eye, every 4 hours, 2 drops of Celunaf eyedrops in the compromised eye every 4 hours and $25 \mathrm{mg}$. of Captopril every 24 hours through oral therapy. The patient attended a follow up, one month posterior to the accident. During this session, the following things were evaluated: bio-acceptability of the material, appropriate wound healing, and ocular mobility degree to asses muscular and nerve damage. The patient referred having inconstant tinnitus, and occasional photopsia, that will be closely monitored. 


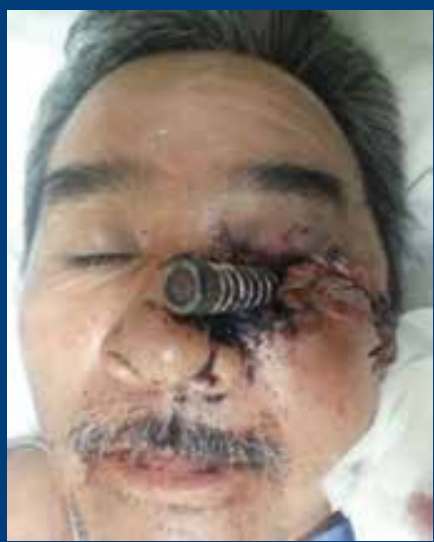

Figure 1.

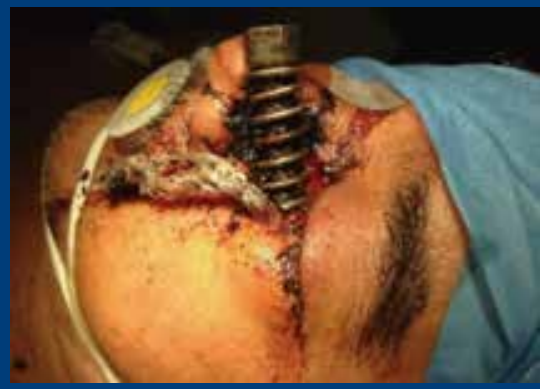

Figure 4.

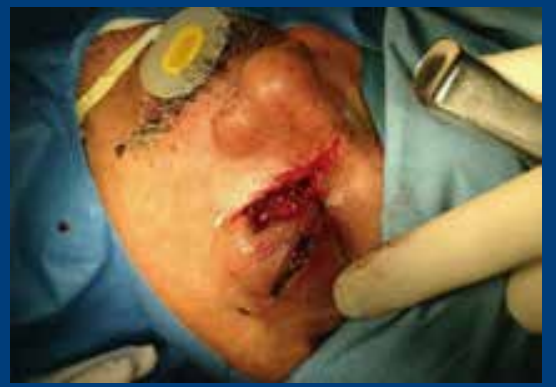

Figure 7.

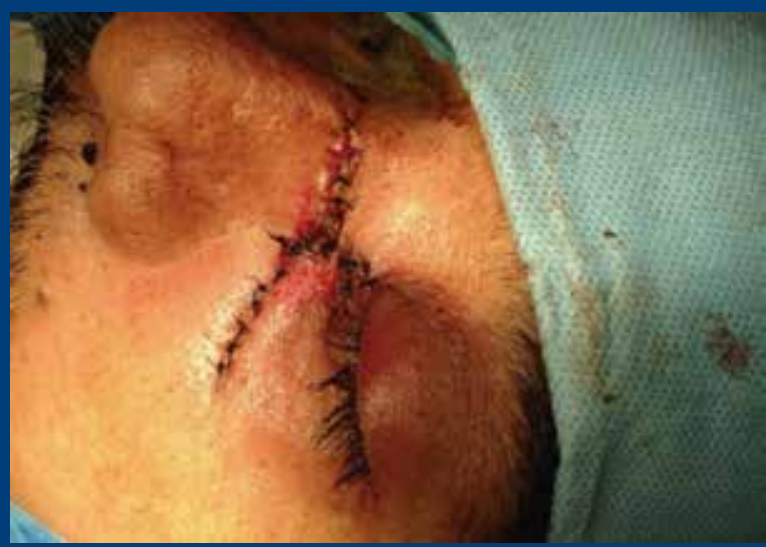

Figure 10.

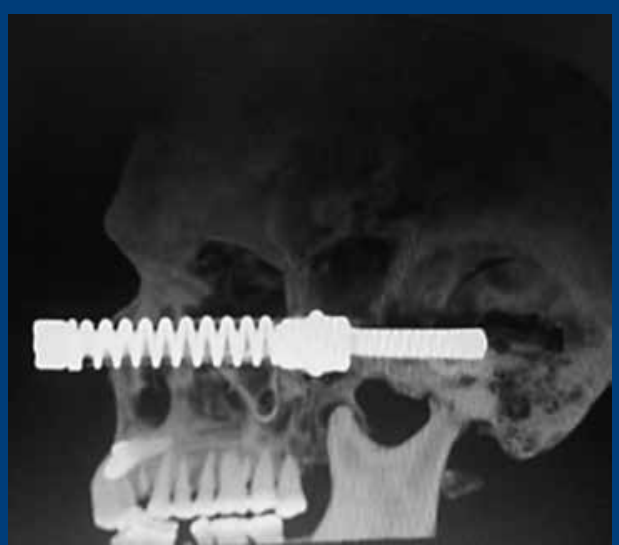

Figure 2.

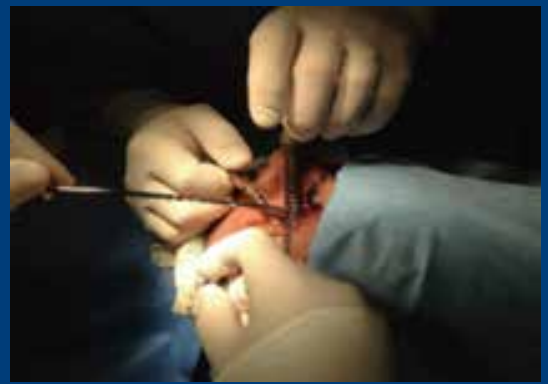

Figure 5.

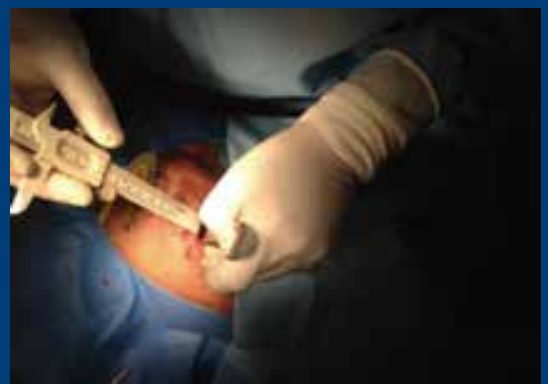

Figure 8.

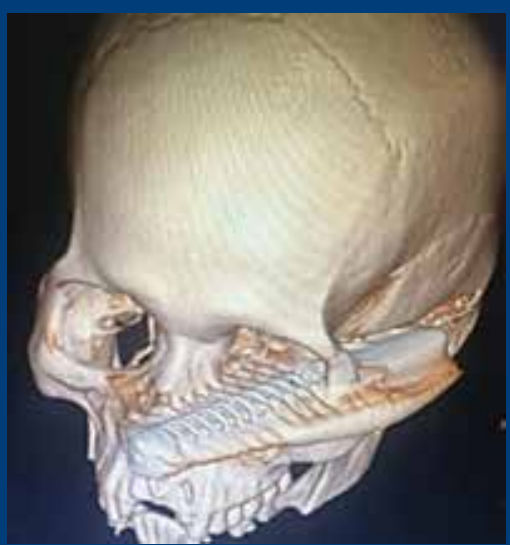

Figure 3.

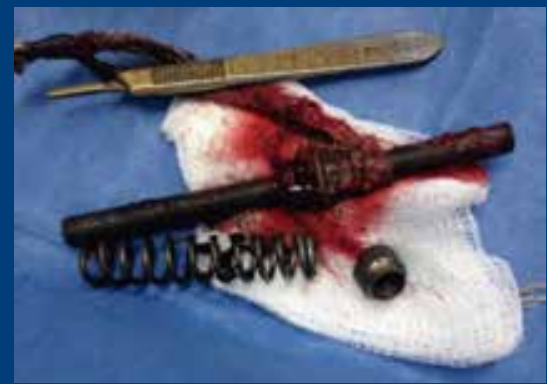

Figure 6.

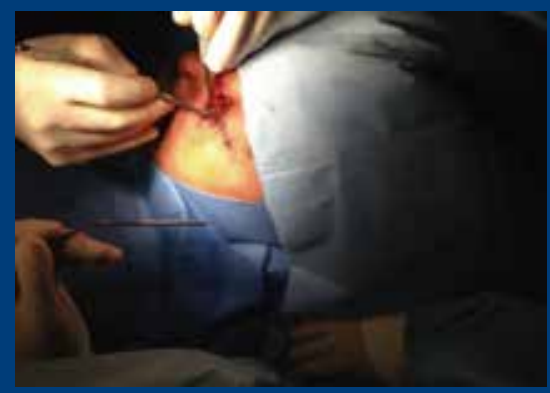

Figure 9.

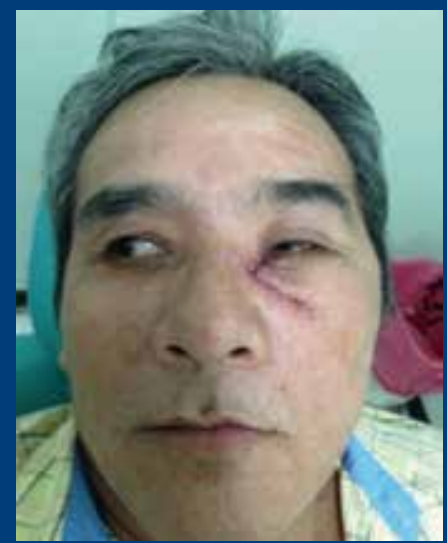

Figure 11.

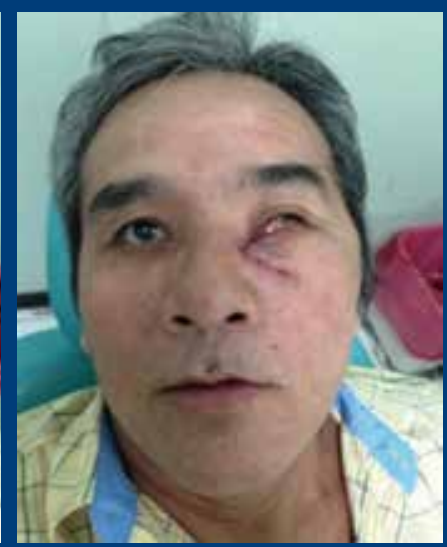

Figure 12. 


\section{DISCUSSION}

The patient presented in the case is another prime example of how a gunshot injury can represent a real challenge at the moment of trying to give an immediate and appropriate response. The patient that attended the medical service fell in an age above (25-30 years old average) what is reported in different studies of firearm injuries $(2,6,10,11,13-15)$. Regarding the sex, he fell in concordance of the majority of studies that mention that men have a higher prevalence of these types of injuries $(3,5,6,10,11,13)$. It has been reported that regarding non intentional firearm injuries, those that happen by a rifle represent the lowest percentage, after handgun, and shotgun injuries(16); this gives the case a more interesting take on the rarity of these lesions.

The buttresses that make up the midface partthe nasomaxillary buttress, the pterygomaxillary, and and the lateral or zygomaticomaxillary one, are very important due to their aid in resisting blows that this area receives $(7,17)$. In the majority of cases, the appropriate approach to treatment of maxillofacial trauma is via early comprehensive repair and simultaneous open reduction for maxillofacial fracture fixation (18). Another great benefit to the treatment is restoring continuity primarily, because if this is done late, fibrosis occurs around bone segments and this creates difficulty in movement, or the tissue may even become necrotic (19). These patients can be submitted to primary debridement and arch bar placement followed by open reduction of the fractures. Additional to arch bars, the use of titanium miniplates are an excellent rehabilitation choice, especially in the public health setting where the patient attended(18). There are newer technologies in the market that allow for more precise and advanced biocompatible options for restoration, such as 3D printed meshes, yet this option of treatment is still limited to a certain population that can afford the cost, as well as practioners that have access to the technology $(20,21)$.

The development of tinnitus (like the one seen in the patient), could be an effect of temporal/ petrous bone fracture or injury (22). It has been reported that tinnitus develops in nearly $50 \%$ of individuals with these types of fractures(23). On the other hand, photpsia has not been reported with high incidence of post traumatic orbital injury, but does form part of the symptoms for severe injury, along with pain, floaters, diplopia and scotomata (24).

\section{CONCLUSION}

As it can be observed, the management of wounds to the infraorbital area is as complex as its treatment. The correct therapeutic and pharmacological approach will permit a better chance of recovery for the patient. The importance of function and aesthetic in this area leads us to promote the reporting of the management of these cases, so knowledge to the correct management can continue.

\section{REFERENCES}

1. Firat C., Geyik Y. Surgical modalities in gunshot wounds of the face. J Craniofac Surg [Internet]. 2013;24(4):1322-6. Available from:http://www.ncbi.nlm.nih.gov/ pubmed/23851799

2. Shackford S. R., Kahl J. E., Calvo R. Y., Kozar R. A., Haugen C. E., Kaups K. L., et al. Gunshot wounds and blast injuries to the face are associated with significant morbidity and mortality. J Trauma Acute Care Surg [Internet]. 2014;76(2):347-52. Available 
from: http://content.wkhealth.com/linkback/ openurl?sid=WKPTLP:landingpage \& an $=01586154-201402000-00013$

3. Tholpady S. S., Demoss P., Murage K.P.,Havlik R.J.,Flores R.L.Epidemiology, demographics, and outcomes of craniomaxillofacial gunshot wounds in a Level i trauma center. J CranioMaxillofacial Surg [Internet]. 2014; 42 (5): 40311. Available from: http://dx.doi.org/10.1016/j. jcms.2013.06.004

4. Allareddy V., Nalliah R., Lee M. K., Rampa S., Allareddy V. Impact of Facial Fractures and Intracranial Injuries on Hospitalization Outcomes Following Firearm Injuries. JAMA Otolaryngol Neck Surg [Internet]. 2014;140 (4): 303. Available from: http://archotol. jamanetwork.com/article.aspx?doi=10.1001/ jamaoto.2014.61

5. Hernández-Téllez I. E., Palmieri-Bouchan R. B., García-Valadez L. R., Ibáñez-Guerrero O., Castellanos-Velazco C.A. Epidemiología de las heridas por proyectil de arma de fuego en el Hospital Central Militar de México. Gunshot wounds Epidemiol Mex Mil Cent Hosp [Internet]. 2015; 69 (3): 204-17. Available from: http://search.ebscohost.com/ login.aspx?direct=true $\& \mathrm{db}=\mathrm{a} 9 \mathrm{~h} \& \mathrm{AN}=1086$ 69027\&lang $=$ es\&site $=$ ehost-live

6. Moye-Elizalde G. A., Ruiz-Martínez F., Suarez-Santamaría J. J., Ruiz-Ramírez M., Reyes-Gallardo A. D-AB. Epidemiología de las lesiones por proyectil de arma de fuego en el Hospital General de Ciudad Juárez, Chihuahua. 2013; 27 (4): 221-35.

7. Yamsani B., Gaddipati R., Vura N., Ramisetti S., Yamsani R. Zygomaticomaxillary Complex Fractures: A Review of 101 Cases. J Maxillofac Oral Surg [Internet]. 2016; 15 (4): 417-24. Available from: http://link.springer. com/10.1007/s12663-015-0851-9
8. Miloro M., Peter G. E. G., Peter E.L. Peterson's Rinciples of Oral and Maxillofacial [Internet]. City. 2004. 1502 p. Available from: www.allislam.net-Problem

9. Norton R. KO. Injuries. N Engl J Med. 2013; 3 (68): 1723-9.

10. Naranjo R., Duque F. AE. Experiencia en el diagnóstico y tratamiento del paciente con trauma maxilofacial por arma de fuego en el servicio de cirugía maxilofacial del hospital universitario de San Vicente Paúl de Medellin entre 1998 y 2003. 2005; 16:33-41.

11. Hollier L., Grantcharova E. P., Kattash M. Facial gunshot wounds: A 4-year experience. J Oral Maxillofac Surg. 2001; 59 (3): 277-82.

12. MaurinO.,deRégloixS.,DubourdieuS.,Lefort H., Boizat S., Houze B., et al. Maxillofacial Gunshot Wounds. Prehosp Disaster Med [Internet]. 2015; 30 (3): 316-9. Available from: http://www.journals.cambridge.org/ abstract_S1049023X1500463X

13. Norris O., Mehra P., Salama A. Maxillofacial Gunshot Injuries at an Urban Level I Trauma Center - 10-Year Analysis. J Oral Maxillofac Surg [Internet]. 2015; 73 (8): 15329. Available from: http://dx.doi.org/10.1016/j. joms.2015.03.019

14. Gray S. T. Epidemiological Survey of Head and Neck Injuries and Trauma in the United States. Otolaryngol Head Neck Surg. 2015; 151 (5): 776-84.

15. José H., González E., Cavazos J. C., Palacios-zertuche J., Reyna-sepúlveda F. Epidemiology of gunshot wounds in the University Autonomous University of Nuevo León. Cir Cir. 2017; 85 (1).

16. Gotsch K. E., Annest J. L., Mercy J. A. RG. Surveillance for fatal and nonfatal firearmrelated injuries-United States 1993-1998. MMWR Morb Mortal Wky Rep. 2001;50. 
17. Pollock R. A. Craniomaxillofacial Buttresses - Anatomy and Operative Repair. Head Neck [Internet]. 2012; 35 (11): 1. Available from: http://books.google.ca/ books?id=RiM70odQU8EC\%5Cnhttp://doi. wiley.com/10.1002/hed.23416

18. Kalantar Motamedi M. H. Comprehensive Management of Maxillofacial Projectile Injuries at the First Operation; "picking up the Pieces." Trauma Mon. 2012; 17 (4): 365-6.

19. Motamedi M. H. Management of firearm injuries to the facial skeleton: Outcomes from early primary intervention. J Emerg Trauma Shock [Internet]. 2011;4 (2): 212. Available from: http://www.onlinejets.org/ text.asp?2011/4/2/212/82208

20. Chia H. N., Wu B. M. Recent advances in 3D printing of biomaterials. J Biol Eng [Internet]. 2015; 9 (1): 4. Available from: http://www. jbioleng.org/content $/ 9 / 1 / 4$

21. Dawood A., Marti B. M., Sauret-Jackson V., Darwood A. 3D printing in dentistry. Bdj
[Internet].2015;219(11):521-9. Available from: http://www.nature.com/doifinder/10.1038/ sj.bdj.2015.914

22. Kreuzer P. M., Landgrebe M., Vielsmeier V., Kleinjung T., De Ridder D., Langguth B. Trauma-Associated Tinnitus. J Head Trauma Rehabil [Internet]. 2014; 29 (5): 432-42. Available from: http://content.wkhealth.com/ linkback/openurl?sid=WKPTLP:landingpag e\&an=00001199-201409000-00006

23. Wysocki J. Cadaveric dissections based on observations of injuries to the temporal bone structures following head trauma. Skull Base. 2005; 15 (2): 99-106.

24. Mellema P. A., Dewan M. A., Lee M. S., Smith S. D., Harrison A. R. Incidence of Ocular Injury in Visually Asymptomatic Orbital Fractures. Ophthalmic Plast Reconstr Surg [Internet]. 2009; 25 (4): 306-8. Available from: http://content.wkhealth.com/ linkback/openurl?sid=WKPTLP:landingpag e\&an $=00002341-200907000-00013$ 